Revista Brasil. Bot., V.31, n.3, p.457-467, jul.-set. 2008

\title{
Morphology and histochemistry of glandular trichomes of Cordia verbenacea DC. (Boraginaceae) leaves
}

\author{
MARÍLIA CONTIN VENTRELLA ${ }^{1,2}$ and CRISTINA RIBEIRO MARINHO ${ }^{1}$
}

(received: January 17, 2008; accepted: June 12, 2008)

\begin{abstract}
Morphology and histochemistry of glandular trichomes of Cordia verbenacea DC. (Boraginaceae) leaves). The objective of this work was to study, using light and fluorescence microscopy and scanning electron microscopy, the morphology and secretory products of glandular trichomes of Cordia verbenacea DC. (Boraginaceae), known as 'baleeira', a species used in folk medicine as anti-inflammatory, analgesic, anti-ulcerogenic and healing agent. Two classes of glandular trichomes were recognized, globular and reniform. A morphological study of the secretory head and the characterization of the secretory product are also presented. Secretory products of globular trichomes consisted of essential oils, whereas reniform trichomes consisted basically of phenolic compounds such as flavonoids. No pre-established regions for releasing secretory products were found.
\end{abstract}

Key words - 'baleeira', essential oil, fenolic compounds, secretory product

RESUMO - (Morfologia e histoquímica de tricomas glandulares de folhas de Cordia verbenacea DC. (Boraginaceae)). O objetivo deste trabalho foi estudar, usando microscopia de luz e de fluorescência e microscopia eletrônica de varredura, a morfologia e o material secretado de tricomas glandulares de Cordia verbenacea DC. (Boraginaceae), conhecida como erva-baleeira, uma espécie utilizada na medicina tradicional como anti-inflamatório, analgésico, anti-úlcera e cicatrizante. Duas classes de tricomas glandulares foram reconhecidas, globular e reniforme. O estudo morfológico da cabeça secretora e a caracterização do material secretado também são apresentados. A secreção dos tricomas globulares caracteriza-se como óleo essencial, enquanto que nos reniformes consiste basicamente de compostos fenólicos, como flavonóides. Nenhuma região pré-estabelecida para a liberação da secreção foi encontrada.

Palavras-chave - compostos fenólicos, erva-baleeira, óleo essencial, secreção

\section{Introduction}

Plants used worldwide in traditional medicine have been studied for its biological activities and secondary metabolites used as active principles for drugs or as chemical models for the synthesis and semi-synthesis of drugs (Balandrin et al. 1985, Svoboda et al. 1998/1999).

Cordia verbenacea DC. (Boraginaceae), known as 'baleeira', is a shrubby species native to sandbank environments along the Brazilian coast. Its aromatic leaves are used in folk medicine as anti-inflammatory, analgesic, anti-ulcerogenic and healing agent, in the form of teas or infusions for internal or topical use (Lorenzi \& Matos 2002, Souza et al. 2004). Several studies have provided foundation for the popular use of this species, by confirming its antimicrobial (Carvalho Jr. et al. 2004, Hernandez et al. 2007), anti-inflammatory (Basile et al. 1989, Sertié et al. 1988, 2005, Ticli et al. 2005, Passos et al. 2007) and light analgesic (Sertié et al. 2005) activities. Phytochemical studies of $C$. verbenacea aerial parts

\footnotetext{
1. Universidade Federal de Viçosa, Departamento de Biologia Vegetal, CEP 36570-000, Minas Gerais, Brazil.

2._Corresponding author: ventrella@ufv.br
}

identified the presence of monoterpenes, sesquiterpenes (Carvalho Jr. et al. 2004), triterpenes (Velde et al. 1982) and flavones (Velde et al. 1982, Lins et al. 1990). Fresh leaves of $C$. verbenacea produce $0.23 \%$ (v/w) of essential oil, having $\alpha$-pinene as main constituent $(29.69 \%)$, transcaryophyllene $(25.27 \%)$, alloaromadendrene $(9.99 \%)$ and alpha-humulene (4.64\%) (Carvalho Jr. et al. 2004).

Studies have demonstrated that the plant secretory products are generally mixed, located in only one secretory structure or compartmentalized in different secretory structures, in vegetative or reproductive organs (Fahn 1979, Ascenção \& Pais 1987, Fahn \& Shimony 1996, Serrato-Valenti et al. 1997, Ascenção et al. 1999, Bisio et al. 1999, Corsi \& Bottega 1999, Monteiro et al. 2001, Machado et al. 2006, Combrinck et al. 2007). In the family Boraginaceae, the glandular trichomes present in the leaves have different morphological patterns and are the typical secretory structures of the group (Solereder 1908, Metcalfe \& Chalk 1957).

The use of $C$. verbenacea in traditional medicine, the phytochemical studies and the proven pharmacological activities show the necessity of better knowledge of the secretory structures related to the production of secondary metabolites in this species. The objective of the present 
work was to characterize morphologically and histochemically the glandular trichomes, using techniques of light, fluorescence and scanning electron microscopy, seeking to establish relationships between trichome morphology and secretory product composition.

\section{Material and methods}

Plant material - The work was carried out at the Plant Anatomy Laboratory, Department of Plant Biology (DBV), and at the Center for Microscopy and Microanalysis (NMM), both located in the Federal University of Viçosa (UFV), Viçosa-MG. Plant material of Cordia verbenacea DC. (Boraginaceae) was collected from a sandbank environment, at the Castelhanos beach, municipal district of AnchietaES, for vegetative propagation by stem cuttings. A voucher specimen was deposited at the VIC Herbarium of the Federal University of Viçosa, under number 26.789. The propagated plants were grown under field conditions at the Botanical Garden of the UFV $\left(20^{\circ} 45^{\prime} \mathrm{S}, 42^{\circ} 55^{\prime} \mathrm{W}, 690 \mathrm{~m}\right.$ a.s.l.) and fresh leaves were collected for the morphological and histochemical analyses.

Light microscopy (LM) - Fresh leaf blades at different developmental stages were sectioned transversally in a tablemicrotome (LPC Rolemberg \& Bherring). The following histochemical reactions were carried out: Sudan red B (Brundrett et al. 1991) and black B (Lison 1960) for lipids, Nile blue sulphate (Cain 1947) for acid and neutral lipids, Nadi reagent (David \& Carde 1964) for essential oils and oleoresins, osmium tetroxide $\left(\mathrm{OsO}_{4}\right)($ Ganter \& Jollés 1969) for unsaturated lipids, periodic acid/Schiff (PAS) reagent (Feder \& O'Brien 1968) for polysaccharides with vicinal glycol groups, Ruthenium red (Johansen 1940) for pectins, Alcian blue (Pearse 1985) for acid mucopolysaccharides, mercuric bromophenol blue (Mazia et al. 1953) and xylidine Ponceau (Vidal 1977) for proteins, ferric trichloride (Johansen 1940) and potassium dichromate (Gabe 1968) for phenolic compounds, hydrochloric vanillin (Mace \& Howell 1974) for tannins, Wagner and Dittmar reagent (Furr \& Mahlberg 1981) for alkaloids, anthimonium trichloride (Mace et al. 1974) for terpenes containing steroids, sulphuric acid (Geissmen \& Griffin 1971) and Abraham reaction (Caniato et al. 1989) for sesquiterpenic lactones, 2-4-dinitrophenylhydrazine (Ganter \& Jollés 1969) for terpenoids. Standard control procedures were carried out simultaneously. The observations were made in light microscope (Olympus AX-70). For the fluorescence microscopy investigation, fresh material was treated with: aluminium trichloride, magnesium acetate and lead neutral acetate (Charrière-Ladreix 1976) for flavonoids, and neutral red (Kirk 1970) for lipids. A epifluorescence microscope (Olympus BX60) equipped with a UV filter (WU: $330-385 \mathrm{~nm}$ ), a dichroic mirror (400 nm) and a barrier filter $(420 \mathrm{~nm})$ were used. The autofluorescence investigation was carried out using the same instrument.
Schematic drawings and head measurements of glandular trichomes were obtained from transversal sections of fresh, young and mature leaves, under light microscope coupled with a camera lucida. Data from 100 measurements per trichome were statistically analyzed.

Scanning electron microscopy (SEM) - Portions of leaves at diferent developmental stages were fixed in FAA in ethanol $50 \%$ for 48 hours, stored in 70\% ethanol (Johansen 1940). After dehydration in a graded ethanol series, the material was criticalpoint dried with $\mathrm{CO}_{2}$, sputter-coated with a thin layer of gold $(20 \mathrm{~nm})$ and, finally, examined in a scanning electron microscopy (LEO $1430 \mathrm{VP}$ ) at an acceleration voltage of $10.6 \mathrm{kV}$.

\section{Results}

Trichome morphology and distribution - Non-glandular and glandular trichomes were present on both leaf surfaces (figures 1-4). Non-glandular trichomes were conical, unicellular, with thick and warty wall and calcified apical portion. Surrounding this trichome base were special subsidiary cells protruding above the level of the other epidermic cells (figures 2, 8). Two types of non-glandular trichomes were found: 1) short, with the development of a body similar to a bulbous cystolith in the basal portion (not shown), on the leaf adaxial surface (figures 1, 2);2) long, with inconspicuous cystolith bodies, leaning over the epidermis, mainly on the major veins of the leaf abaxial surface (figures 3,4).

Glandular trichomes (figure 5) consisted of an epidermic basal cell, a uniseriate stalk and a unicellular secretory head. The stalk can be short, formed by a single cell, or long with up to ten cells; and the upper cell showed a special type of differentiation, as a neck cell. The form and type of insertion of the secretory head allowed the distinction of two classes of glandular trichomes: 1) globular type (figures 5E-F, 6, 9), with spherical secretory head, attached to the stalk by the usual way, having $33.68 \pm 3.64 \mu \mathrm{m}$ mean diameter, regardless of the stalk cell number, and short neck cell; 2) reniform type (figures $5 \mathrm{~A}-\mathrm{D}, 7,8$ ), with elipsoidal head attached to the stalk by one end, measuring 35.79 $\pm 5.02 \times 24.15 \pm 3.0 \mu \mathrm{m}$ when the stalk was short (just one cell), and $50.72 \pm 5.66 \mu \mathrm{m} \times 30.48 \pm 3.45 \mu \mathrm{m}$ when the stalk was long (2-10 cells); neck cell long and curved. Globular and reniform glandular trichomes occured side by side on both leaf surfaces, being much more abundant on the abaxial surface. The short globular and reniform trichomes were more abundant and located in intervenal regions, whereas the long ones were scarcer and located along the veins, mainly on the abaxial surface. Globular and reniform trichomes with broken cuticle in the equatorial 

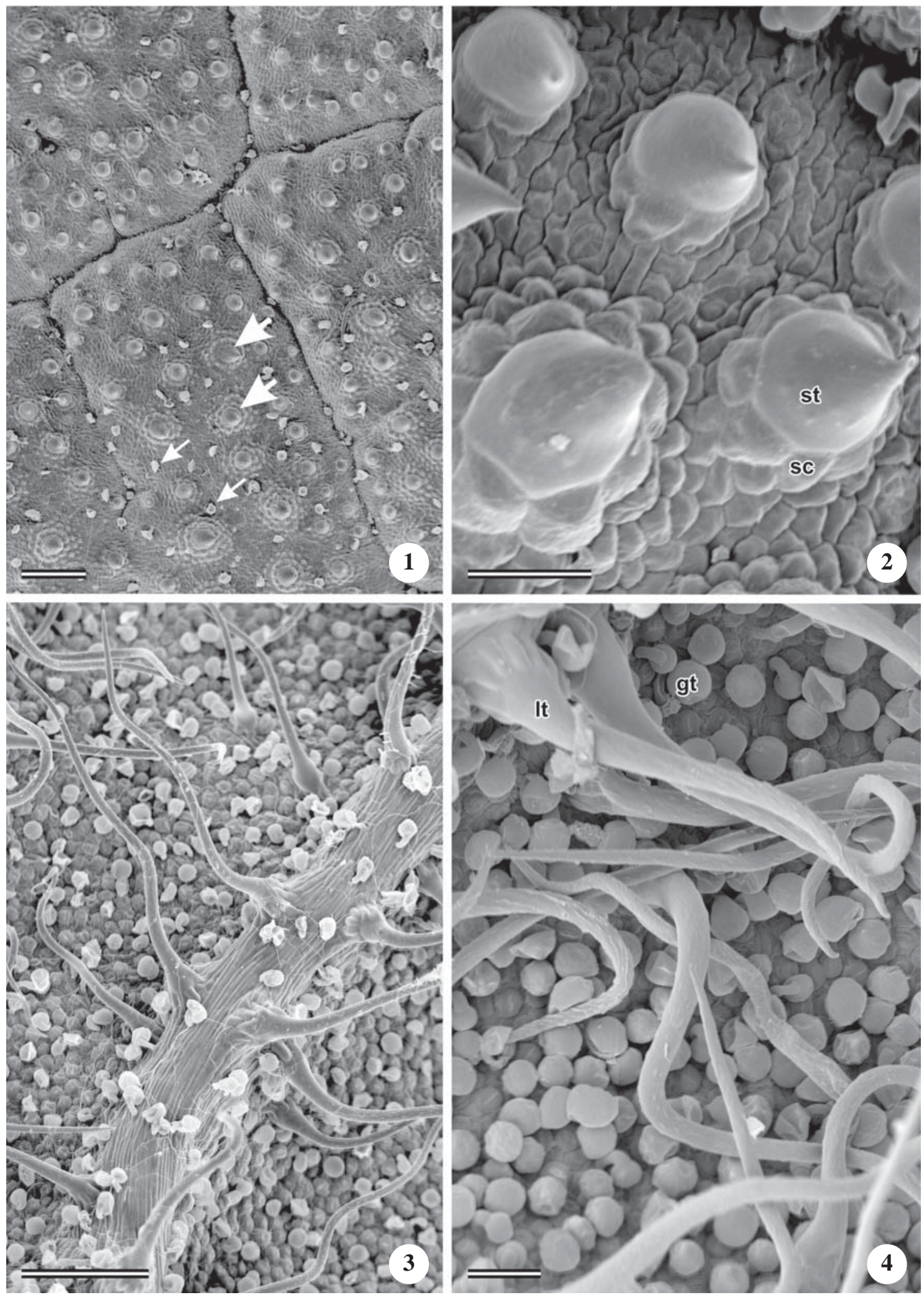

Figures 1-4. Scanning electron micrographs of Cordia verbenacea leaves. 1-2. Adaxial surface showing short non-glandular trichomes (large arrows) and scattered glandular trichomes (narrow arrows). Note the subsidiary cells bearing the hair and protrunding above the level of the other epidermal cells. 3-4. Abaxial surface, showing long non-glandular trichomes restricted to the veins and a large amount of glandular tricomes. $(\mathrm{gt}=$ glandular trichome; $1 \mathrm{t}=$ long non-glandular trichome; $\mathrm{sc}=$ subsidiary cell; $\mathrm{st}=$ short non-glandular trichome) $. \mathrm{Bar}=200 \mu \mathrm{m}(1,3) ; 50 \mu \mathrm{m}(2,4)$. 

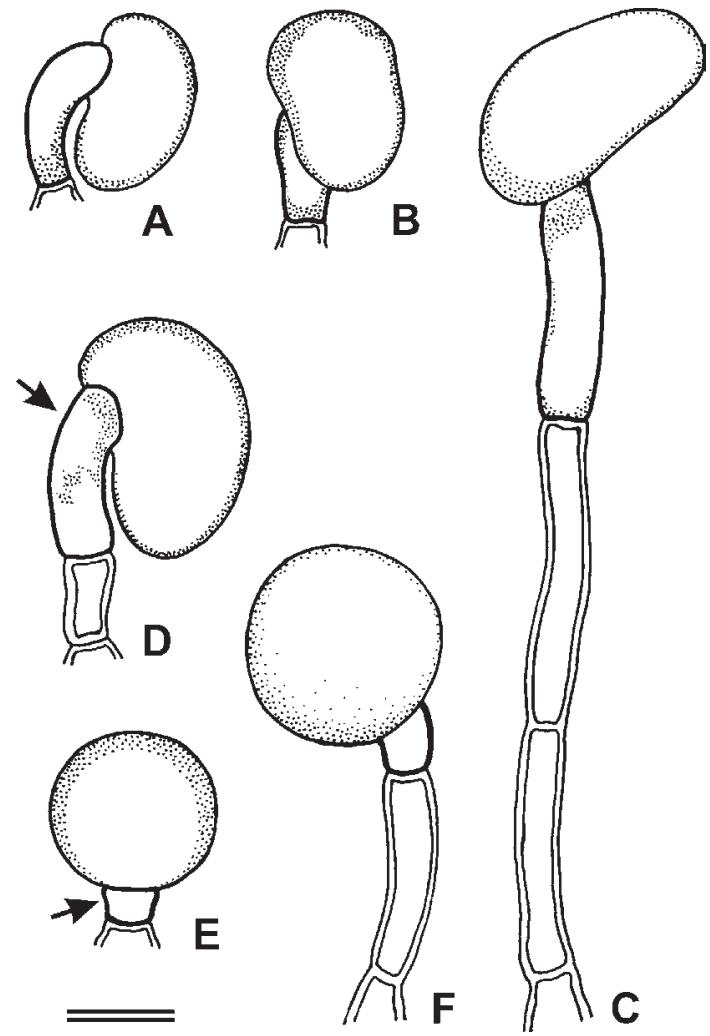

Figure 5. Schematic drawings of different types of glandular trichomes of Cordia verbenacea leaves. A-D. Reniform trichomes. E-F. Globular trichomes. The number of stalk cells varies in both globular and reniform trichomes, but the upper stalk cell is always distinct, like a neck-cell (arrows). Bar $=25 \mu \mathrm{m}$. region of the secretory head cell were found (figures 7, 9), but neither pores nor pre-established regions for secretion release were observed. Globular and reniform trichomes were already present and fully differentiated at early stages of leaf development. On expanded mature leaves the glandular trichomes were still active and occured in a sparse distribution.

Histochemistry of glandular trichomes - Table 1 shows the results of histochemical tests for globular and reniform trichomes.

Globular trichomes - The secretory product of globular trichomes was light yellow in color, abundant, and located in the subcuticular chamber (figure 10). Staining with Sudan red (figure 11) and Sudan black B (figure 12) showed positive lipid reaction in both the head cells and neck cell walls (figures 11, 12). The secretory product can be observed within the subcuticular chamber stained in red (figure 11) or dark blue (figure 12), characteristic of Sudan red B and Sudan black B respectively. The whole head of globular trichomes was intensely black stained by osmium tetroxide (figure 13), indicating the presence of unsaturated lipids in the whole secretory cell. Neutral lipids were identified by a pink color with Nile blue sulphate (figure 14). Essential oils were identified in the secretion composition by the violet-blue color with a Nadi reaction (figure 15), whereas oil-resins were absent. Polysaccharides, as pectin, only occurred within protoplasts of secretory cells, but the secretory product had no reaction for this group of compounds with

Table 1. Compounds identified by histochemical tests and/ or fluorescence microscopy in globular (G) and reniform (R) trichomes of Cordia verbenacea leaves.

\begin{tabular}{|c|c|c|c|c|}
\hline \multirow{2}{*}{ Test } & \multirow{2}{*}{ Compound } & \multirow{2}{*}{ Colour observed } & \multicolumn{2}{|c|}{ Type of trichome } \\
\hline & & & G & $\mathrm{R}$ \\
\hline Sudan red B & lipids & red & $*$ & \\
\hline Sudan black B & lipids & dark blue & $*$ & \\
\hline Nile blue & $\begin{array}{l}\text { acid lipids } \\
\text { neutral lipids }\end{array}$ & $\begin{array}{l}\text { blue } \\
\text { pink }\end{array}$ & $*$ & $*$ \\
\hline Nadi reagent & essential oils & violet-blue & $*$ & \\
\hline Osmium tetroxide & unsaturated lipids & black & $*$ & $*$ \\
\hline Neutral red & lipids & $\begin{array}{l}\text { yellow } \\
\text { blue }\end{array}$ & $*$ & $*$ \\
\hline Ruthenium red & pectins & rose & $*$ & $*$ \\
\hline Ferric trichloride & phenolic compounds & black & & $*$ \\
\hline Potassium dicromate & phenolic compounds & brown & & $*$ \\
\hline Aluminium trichloride & flavonoids & yellow-greenish & & $*$ \\
\hline Magnesium acetate & flavonoids & yellow-greenish & & $*$ \\
\hline Lead neutral acetate & flavonoids & yellow-greenish & & $*$ \\
\hline
\end{tabular}



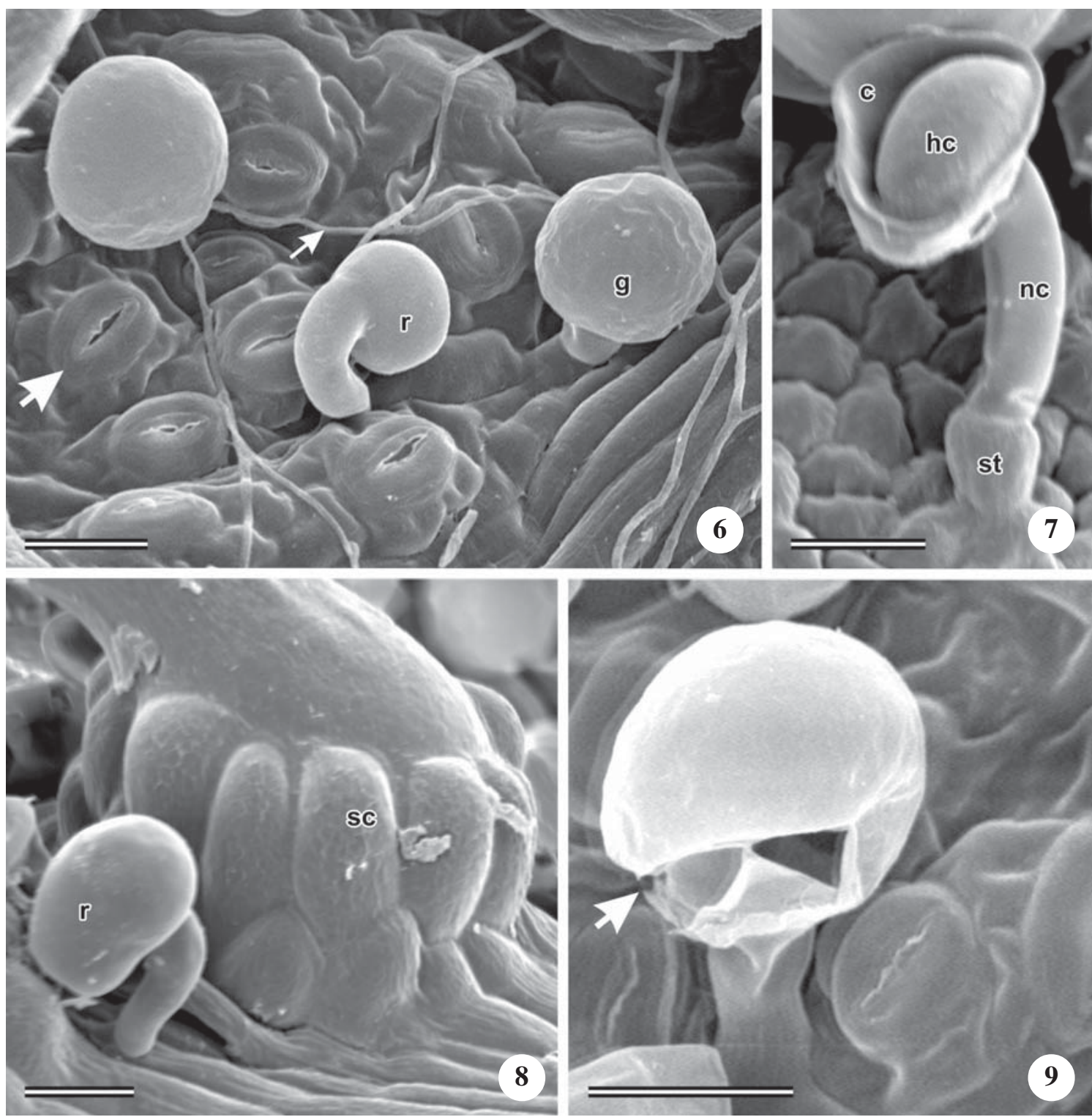

Figures 6-9. Scanning electron micrographs of Cordia verbenacea leaves. 6. Glandular trichomes on the abaxial surface, and stomata (large arrow) projected above the level of the other epidermal cells. Hyphae (narrow arrow) on epidermal surface. 7. Adaxial surface, reniform trichome showing broken cuticle and exposed secretory head cell; stalk consisting of two cells, where the apical cell differentiated into a long and curved neck cell. 8. Abaxial surface; note a reniform trichome and subsidiary cells surrounding the non-glandular trichome. 9. Globular trichome with broken cuticle (arrow) in the equatorial region of the head cell. $(\mathrm{c}=$ cuticle; $\mathrm{g}=$ globular trichome; $\mathrm{hc}=$ secretory head cell; $\mathrm{nc}=$ neck cell; $\mathrm{r}=$ reniform trichome; sc = subsidiary cell; st $=$ stalk cell). Bar $=20 \mu \mathrm{m}$.

Ruthenium red, remaining clear (figure 16). Globular trichomes showed blue autofluorescence under ultraviolet light, mainly the secretory head (figure 17). The presence of lipids was confirmed by the intense yellow fluorescence with neutral red fluorochrome (figure 18). For the other histochemical tests, either under light or fluorescence microscopy, the reaction was negative or similar to the control.
Reniform trichomes - In these trichomes, the secretion was more scarce and lighter in color (figure 19), and subcuticular space formation was only observed through scanning electron microscopy, with broken cuticle (figure 7 ). The presence of structural lipids on neck cell walls was confirmed by the red staining with Sudan red (figure 20). Lipid classes were not found in the secretion of reniform trichomes, although the osmium tetroxide 

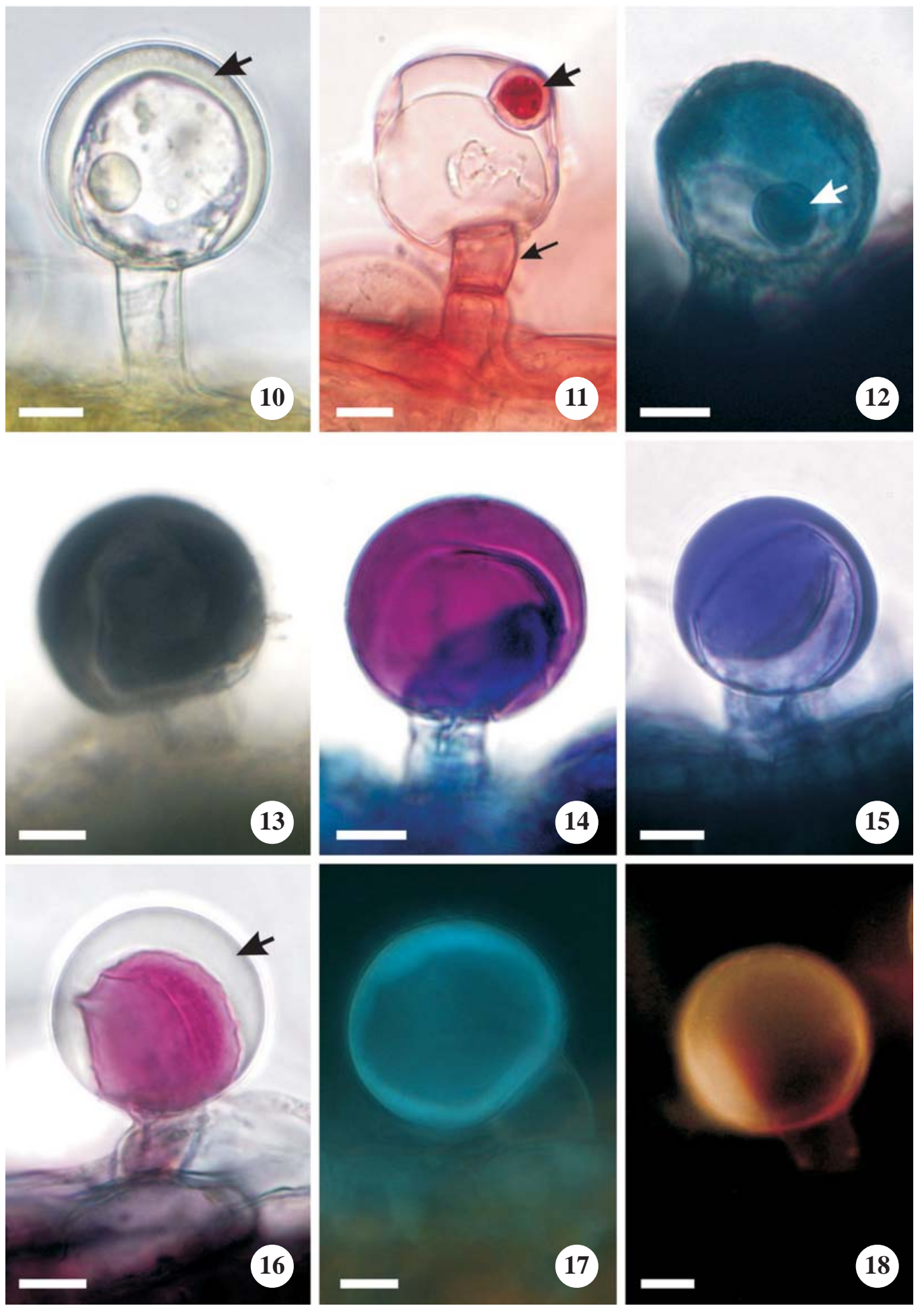

Figures 10-18. Light (10-16) and fluorescence micrographs under UV light (17-18) showing the response of globular glandular trichomes of Cordia verbenacea leaves to histochemical tests. 10. In vivo. The secreted material appears to be oily; arrow shows the secreted material in a subcuticular space. 11. Characteristic red color of lipids stained with Sudan red B (large arrow). The neck-cell walls also stained red (narrow arrow). 12. Lipids stained dark blue with Sudan black B (arrow). 13. $\mathrm{OsO}_{4}$ test showing black staining of the unsaturated lipids. 14. Pink stained of neutral lipids with Nile blue test. 15. Essential oils stained violet-blue with Nadi reagent. 16. Pectins stained pink with Rutenium red at the secretory head cell. Note that the secretion in the subcuticular space (arrow) was not stained. 17. Blue autofluorescence of the head cell under UV light. 18. Intense yellow fluorescence with neutral red. Bar $=10 \mu \mathrm{m}$. 

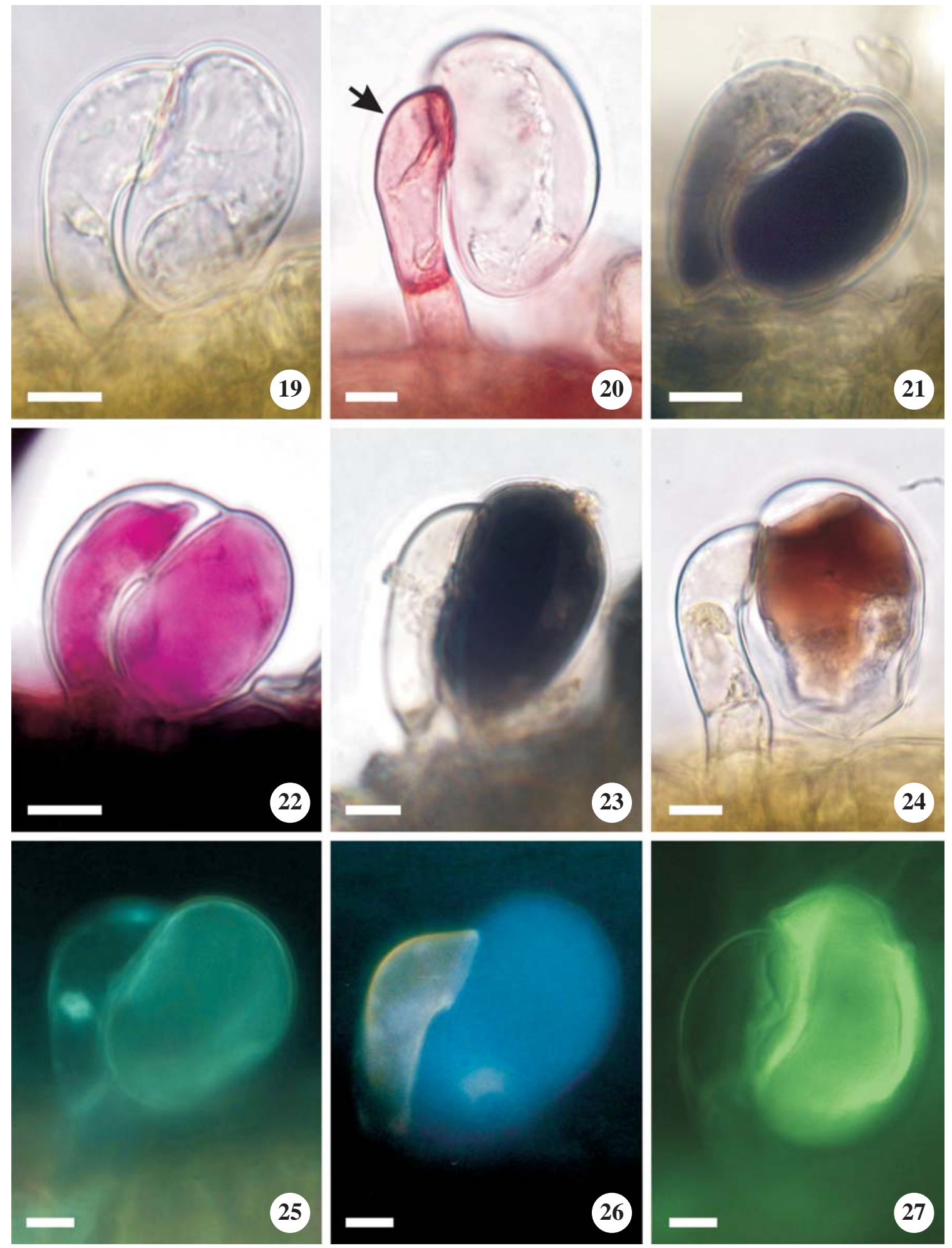

Figures 19-27. Light (19-24) and fluorescence micrographs under UV light (25-27) showing the response of reniform glandular trichomes of Cordia verbenacea leaves to histochemical tests. 19. In vivo. 20. Sudan red B; positive reaction just in a neck-cell walls (arrow). 21. $\mathrm{OsO}_{4}$ test showing black staining in the secretory head cell. 22. Pectins stained pink with Ruthenium red in secretory head cell and neck cell. The neck cell walls have not reacted (arrow). 23. Phenolic compounds stained black with ferric trichloride test. 24. Brown color of phenolic compounds with potassium dicromate. 25 . Weak green-blue autofluorescence under UV ligh. 26. Intense blue fluorescence with neutral red. 27. Intense green fluorescence of the head cell stained by aluminium trichloride. $\mathrm{Bar}=10 \mu \mathrm{m}$. 
reaction stained the secretory head intensively black (figure 21). Ruthenium red showed pectin within the head and neck cells, which became rose (figure 22). Phenolic compounds were present in the secretion, confirmed by the black color when stained with ferric trichloride (figure 23) or by brown color with potassium dichromate (figure 24). Under ultraviolet light, the reniform trichomes showed weak green-blue autofluorescence (figure 25). With neutral red fluorochrome, these trichomes showed intense blue fluorescence (figure 26), indicating different chemical nature in comparison to globular trichomes, which fluoresce intense yellow under UV light. Flavonoids were identified with fluorochrome, fluorescing intense green under UV light, mainly when stained with aluminum chloride (figure 27). As for the other histochemical tests, either under light or fluorescence microscopy, the reaction was negative or similar to the control.

\section{Discussion}

The non-glandular trichomes associated with cystolith bodies in the basal portion and with partially calcified walls, called cystolith-hairs, are widely distributed in Boraginaceae and responsible for the wrinkled leaf surface (Solereder 1908, Metcalfe \& Chalk 1957). In C. verbenacea, the development of cystolith bodies was more evident in short non-glandular trichomes with appear on the leaf adaxial surface.

The morphology and the distribution of glandular trichomes in C. verbenacea were similar to those described for other species of the genus (Solereder 1908, Metcalfe $\&$ Chalk 1957), being always uniseriate, with unicellular secretory head and a typical shape. Despite of the variation in the number of stalk cells and in the size of the head cells, glandular trichomes could be classified as globular or reniform, according to the morphology of the head cell. Structural lipids, probably cutin or suberin, were present on neck cell walls, as shown by the positive reaction with Sudan red B and the negative reaction with Ruthenium red. This endodermal feature is commom in oil-secreting trichomes, which prevent backward-flow of the secreted material (Fahn 1979, Werker 2000). Neck cells with cutinized lateral walls were also found in species of Scrophulariaceae (Sacchetti et al. 1999) and Lamiaceae (Bosabalidis \& Tsekos 1982, Bisio et al. 1999), although in peppermint (Lamiaceae) they were not described as cutinized, but as suberized walls (Turner et al. 2000).

Both glandular trichomes apparently accumulates their secretory product within the subcuticular space, as in glandular trichomes of Lamiaceae (Bosabalidis \& Tsekos 1982, Werker et al. 1985, Ascensão et al. 1995,
1997, 1999, Bisio et al. 1999, Serrato-Valenti et al. 1997, Turner et al. 2000), Scrophulariaceae (Sacchetti et al. 1999), Asteraceae (Ascensão \& Pais 1987, Figueiredo \& Pais 1994) and Bignoniaceae (Machado et al. 2006). Secretion release in glandular trichomes can take place by the rupture of the cuticle in regions of greater fragility (Ascensão \& Pais 1987, Figueiredo \& Pais 1994, Ascensão et al. 1995, Serrato-Valenti et al. 1997, Bisio et al. 1999), through pores in the cuticle (Bisio et al. 1999, Ascensão et al. 1999) or even diffusion through the cuticle (SerratoValenti et al. 1997). Although trichomes with broken cuticle were found in $C$. verbenacea, no pores or regions indicating secretion release were observed, suggesting that the secretion is released to the environment through a rupture of the cuticle caused by mechanical damage.

The secretion of globular trichomes was oily and predominantly lipophilic, whereas reniform trichomes had hydrophilic secretion. The osmium tetroxide test indicated the presence of lipids in the composition of globular trichome secretion, with prevalence of unsaturated lipids, relatively large number of double bonds, and consequently low melting point, determining the fluidity of the secretion at room temperature. Although the osmium tetroxide test also indicated lipids in reniform trichome secretion, it should be considered that this is a broad-spectrum reagent, reacting not only with unsaturated lipids, but also with phenolic compounds, proteins and alkaloids (Jensen 1962, Machado et al. 2006), staining both secretion and protoplasts of secretory cells. Neutral lipids, such as essential oils, were restricted to the globular trichome secretion, and the positive reaction of reniform trichomes to osmium tetroxide can be attributed to phenolic compounds present in this class of trichomes. The difference in the autofluorescence pattern under light UV for the two types of trichomes also indicates differences in the secretory activity, with globular trichomes having blue autofluorescence and reniform trichomes showing weak autofluorescence in the head. When globular trichomes were stained with neutral red, they showed an intense yellow fluorescence, whereas reniform trichomes showed blue fluorescence, confirming the different chemical nature of their secretion. The blue fluorescence of reniform trichomes can be a consequence of this fluorochrome reaction with structural lipids, such as, plasma membrane phospholipids, but not with the secretion itself.

The occurrence of terpenes in the essential oil of globular trichomes was indicated by the positive reaction with Nadi reagent and confirmed by the characteristic scent of leaves and phytochemical studies that identified high proportions of mono- and sesquiterpenes, such as $\alpha$-pinene, trans-caryophyllene, alloaromadendrene and 
$\alpha$-humulene (Carvalho Jr. et al. 2004). Terpene-rich essential oils are commonly found in the secretion of glandular trichomes of different species (Werker et al. 1985, Ascensão \& Pais 1987, Serrato-Valenti et al. 1997, Ascensão et al. 1999, Bisio et al. 1999, Sacchetti et al. 1999, Turner et al. 2000, Machado et al. 2006). Several biological activities are attributed to essential oils, which were recognized as phytoalexins, insect antifeedant, feromones, defensive agents, allelochemicals or signaling molecules (Harbone 1997). The C. verbenacea essential oil has antimicrobial activity (Carvalho Jr. et al. 2004), and two of its components, a-humulene and transcaryophyllene, were reported to have anti-inflammatory properties (Passos et al. 2007), which is one of the main pharmacological characteristics of the species (Sertie et al. 1988, Basile et al. 1989, Sertié et al. 2005).

The ferric trichloride test, which is based on the formation of intensively colored precipitate from the reaction of iron with ortho-dihydroxyphenols (Johansen 1940), and the potassium dichromate test, which is based on the formation of a product colored by the condensation of free phenolic hydroxyl groups with the chromium of the reagent (Gabe 1968), indicated that phenolic compounds were present only in reniform trichomes. The only class of phenolic compounds histochemically identified in these trichomes, by fluorochromes under UV light, was the flavonoids. Two flavones were already isolated and identified in C. verbenacea, 5,6'-dihydroxy3,6,7,3',4' -pentamethoxyflavone and 5-hydroxy3,6,7,3', ''-pentametoxyflavone, being the latter identical to artemetin that was initially isolated from Artemisia (Asteraceae) species (Velde et al. 1982, Lins et al. 1990). Approximately 8,000 phenolic compounds were already identified in plants, having biological role generally related to antifungal, antibacterial and antifeedant activities of some structures (Harbone 1997).

Although Ruthenium red indicated the presence of acid polysaccharides, as pectin (Johansen 1940), in both globular and reniform trichomes, this result must be analyzed with caution. First, because the positive reaction (rose color) did not extend to the secretion content of the subcuticular space of globular trichomes, and second because it was not specific to the head of reniform trichomes. Therefore, it may be concluded that this class of compound can be present in cell protoplasts as a precursor of the secretory product.

In resume, it can be concluded that the chemical composition of the secretion of glandular trichomes in C. verbenacea is related to the morphology of the secretory head, regardless of its size and the stalk cell number. The secretion of globular trichomes consists mainly of essential oils, whereas the secretion of reniform trichomes consists basically of phenolic compounds, such as flavonoids.

\section{References}

ASCENSÃO, L. \& PAIS, M.S.S. 1987. Glandular trichomes of Artemisia campestris (ssp. maritima): ontogeny and histochemistry of the secretory product. Botanical Gazette 148:221-227.

ASCENSÃO, L., MARQUES, N. \& PAIS, M.S. 1995. Glandular trichomes on vegetative and reproductive organs of Leonotis leonurus (Lamiaceae). Annals of Botany 75:619-626.

ASCENSÃO, L., MARQUES, N. \& PAIS, M.S.S. 1997. Peltate glandular trichomes of Leonotis leonurus leaves: ultrastructure and histochemical characterization of secretions. International Journal of Plant Sciences 158:249-258.

ASCENSÃO, L., MOTA, L. \& CASTRO, M. DE M. 1999. Glandular trichomes of the leaves and flowers of Plectranthus ornatus: morphology, distribution and histochemistry. Annals of Botany 84:434-447.

BALANDRIN, M.F., KLOCKE, J.A., WURTELE, E.S. \& BLLINGER, W.H. 1985. Natural plant chemicals: sources of industrial and medicinal materials. Science 228:1154-1160.

BASILE, A.C., SERIÉ, J.A.A., OSHIRO, T., CALY, K.D.V. \& PANIZZA, S. 1989. Topical anti-inflamatory activity and toxicity of Cordia verbenacea. Fitoterapia 60:260-263.

BISIO, A., CORALLO, A., GASTALDO, P., ROMUSSI, G., CIARALLO, G., FONTANA, N., DE TOMMASI, N. \& PROFUMO, P. 1999. Glandular hairs and secreted material in Salvia blepharophylla Brandegee ex Epling grown in Italy. Annals of Botany 83:441-452.

BOSABALIDIS, A. \& TSEKOS, I. 1982. Glandular scale development and essential oil secretion in Origamum dictamnus L. Planta 156:496-504.

BRUNDRETT, M.C., KENDRICK, B. \& PETERSON, C.A. 1991. Efficient lipid staining in plant material with Sudan Red 7B or Fluoral Yellow 088 in polyethylene glycolglycerol. Biotecninc \& Histochemistry 66:111-116.

CAIN, A.J. 1947. The use of Nile Blue in the examination of lipids. Quarternary Journal of Microscopy Science 88: 111-116.

CANIATO, R., FILIPPINI, R., CAPPELLETTI, E.M. \& APPENDINO, G. 1989. Detection of peroxides in intact plant material. Fitoterapia 60:549-551.

CARVALHO JUNIOR, P.M. de, RODRIGUES, R.F.O., SAWAYA, A.C.H.F., MARQUES, M.O.M. \& SHIMIZU, M.T. 2004. Chemical composition and antimicrobial activity of the essential oil of Cordia verbenacea DC. Journal of Ethnopharmacology 95:297-301.

CHARRIÈRE-LADREIX, Y. 1976. Répartition intracellulaire du secrétat flavonique de Populus nigra L. Planta 129: 167-174. 
COMBRINCK, S., DU PLOOY, G.W., MCCRINDLE, R.I. \& BOTHA, B.M. 2007. Morphology and histochemistry of the glandular trichomes of Lippia scaberrima (Verbenaceae). Annals of Botany 99:1111-1119.

CORSI, G. \& BOTTEGA, S. 1999. Glandular hairs of Salvia officinalis: new data on morphology, localization and histochemistry in relation to function. Annals of Botany 84:657-664.

DAVID, R. \& CARDE, J.P. 1964. Coloration différentielle des inclusions lipidique et terpéniques des pseudophylles du pin maritime au moyen du réactif Nadi. Comptes Rendus de l'Académie des Sciences, Paris 258:13381340 .

FAHN, A. 1979. Secretory tissues in plants. Academic Press, London.

FAHN, A. \& SHIMONY, C. 1996. Glandular trichomes of Fagonia L. (Zygophyllaceae) species: structure, development and secreted materials. Annals of Botany 77:25-34.

FEDER, N. \& O'BRIEN, T.P. 1968. Plant microthecnique: some principles and new methods. American Journal of Botany 55:123-142.

FIGUEIREDO, A.C. \& PAIS, M.S. 1994. Ultrastructural aspects of the glandular cells from the secretory trichomes and from the cell suspension cultures of Achillea millefolium L. ssp. millefolium. Annals of Botany 74:179-190.

FURR, M. \& MAHLBERG, P.G. 1981. Histochemical analyses of laticifers and glandular trichomes in Cannabis sativa. Journal of Natural Products 44:153-159.

GABE, M. 1968. Techniques histologiques. Masson \& Cie, Paris.

GANTER, P. \& JOLLÉS, G. 1969. Histochimie normale et pathologique. v.1, 2. Gauthier-Villars, Paris.

GEISSMAN, T.A. \& GRIFFIN, T.S. 1971. Sesquiterpene lactones: acid-catalyzed color reactions as an aid in structure determination. Phytochemistry 10:2475-2485.

HARBONE, J.B. 1997. Plant secondary metabolism. In Plant Ecology. (M.J. Crawley, eds.) Blackwell Publishing, Berlin, p.132-155.

HERNANDEZ, T., CANALES, M., TERAN, B., ÁVILA, O., DURAN, A., GARCIA, A.M., HERNANDEZ, H., ANGELES-LOPEZ, O., FERNANDEZ-ARAIZA, M. \& ÁVILA, G. 2007. Antimicrobial activity of the essential oil and extracts of Cordia curassavica (Boraginacae). Journal of Ethnopharmacology 111:137-141.

JENSEN, W.A. 1962. Botanical histochemistry: principles and practice. Freeman, San Francisco.

JOHANSEN, D.A. 1940. Plant microtechnique. McGrawHill, New York.

KIRK JUNIOR, P.W. 1970. Neutral red as a lipid fluorochrome. Stain Technology 45:1-4.

LINS, A.P., ALVARENGA, M.A., GOTTLIEB, O.R. \& OLIVEIRA, F. 1990. Two flavonois from Cordia verbenacea. Revista Latino-Americana de Química 21:82.
LISON, L. 1960. Histochemie et cytochemie animals. Principes et méthods, v.1, 2. Gauthier-Villars, Paris.

LORENZI, H. \& MATOS, F.J.A. 2002. Plantas medicinais do Brasil: nativas e exóticas. Instituto Plantarum, Nova Odessa.

MACE, M.E. \& HOWELL, C.R. 1974. Histochemistry and identification of condensed tannin precursor in roots of cotton seedlings. Canadian Journal of Botany 52: 2423-2426.

MACE, M.E., BELL, A.A. \& STIPANOVIC, R.D. 1974. Histochemistry and isolation of gossypol and related terpenoids in roots of cotton seedlings. Phytophatology 64:1297-1302.

MACHADO, S.R., GREGÓRIO, E.A. \& GUIMARÃES, E. 2006. Ovary peltate trichomes of Zeyheria montana (Bignoniaceae): developmental ultrastructure and secretion in relation to function. Annals of Botany 97:357-369.

MAZIA, D., BREWER, P.A. \& ALFERT, M. 1953. The cytochemistry staining and measurement of protein with mercuric bromophenol blue. Biological Bulletim 104: 57-67.

METCALFE, C.R. \& CHALK, L. 1957. Anatomy of the dicotyledons. v.2. Oxford University Press, Oxford.

MONTEIRO, W.R., CASTRO, M. DE M., MAZZONIVIVEIROS, S.C. \& MAHLBERG, P.G. 2001. Development and some histochemical aspects of foliar glandular trichomes of Stevia rebaudiana (Bert.) Bert. Asteraceae. Revista Brasileira de Botânica 24:349-357.

PASSOS, G.F., FERNANDES, E.S., CUNHA, F.M. DA, FERREIRA, J., PIANOWSKI, L.F., CAMPOS, M.M. \& CALIXTO, J.B. 2007. Anti-inflamatory and antiallergic properties of the essential oil and active compounds from Cordia verbenacea. Journal of Ethnopharmacology 110:323-333.

PEARSE, A.G.E. 1985. Histochemistry theoretical and applied. $4^{\text {th }}$ ed. Churchill Livingstone, London.

SACCHETTI, G., ROMAGNOLI, C., NICOLETTI, M., DI FABIO, A., BRUNI, A. \& POLI, F. 1999. Glandular trichomes of Calceolaria adscendens Lindl. (Scrophulariaceae): histochemistry, development and ultrastructure. Annals of Botany 83:87-92.

SERRATO-VALENTI, G., BISIO, A., CORNARA, L. \& CIARALLO, G. 1997. Structural and histochemical investigation of the glandular trichomes of Salvia aurea L. leaves, and chemical analysis of the essential oil. Annals of Botany 79:329-336.

SERTIÉ, J.A.A., BASILE, A.C., PANIZZA, S., MATIDA, A.K. \& ZELNIK, R. 1988. Pharmacological assay of Cordia verbenacea. Part 1. Anti-inflamatory activity and toxicity of the crude extract of the leaves. Planta Medica 54:7-10.

SERTIÉ, J.A.A., WOISKY, R.G., WIEZEL, G. \& RODRIGUES, M. 2005. Pharmacological assay of Cordia verbenacea $\mathrm{V}$ : oral and topical anti-inflammatory activity, analgesic effect and fetus toxicity of a crude leaf extract. Phytomedicine 12:338-344. 
SOLEREDER, H. 1908. Systematic anatomy of the dicotyledons. v.1. Claredom Press, Oxford.

SOUZA, G.C., HAAS, A.P.S., VON POSER, G.L., SCHAPOVAL, E.E.S. \& ELISABETSKY, E. 2004. Ethnopharmacological studies of antimicrobial remedies in the south of Brazil. Journal of Ethnopharmacology 94:135-143.

SVOBODA, K., HAMPSON, J. \& HUNTER, T. 1998/1999. Secretory tissues: storage and chemical variation of essential oils in secretory tissues of higher plants and their bioactivity. The International Journal of Aromatherapy 9:124-131.

TICLI, F.K., HAGE, L.I.S., CAMBRAIA, R.S., PEREIRA, O. S., MAGRO, A.J., FONTES, M.R.M., STÁBELI, R.G., GIGLIO, J.R., FRANÇA, S.C., SOARES, A.M. \& SAMPAIO, S.V. 2005. Rosmarinic acid, a new snake venom phospholipase A2 inhibitor from Cordia verbenacea (Boraginaceae): antiserum action potentiation and molecular interaction. Toxicon 46:318-327.
TURNER, G.W., GERSHENZON, J. \& CROTEAU, R.B. 2000. Development of peltate glandular trichomes of peppermint. Plant Physiology 124:665-679.

VELDE, V.V., LAVIE, D., ZELNIK, R. \& MATIDA, A.K. 1982. Cordialin A and B, two new triterpenes from Cordia verbenacea DC. Journal of the Chemical Society Perkin Trans 1:2697-2700.

VIDAL, B.C. 1977. Acid glycosaminoglycans and endochondral ossification: microespectrophotometric evaluation and macromolecular orientation. Cell Molecular Biology 22:45-64.

WERKER, E. 2000. Trichome diversity and development. In Advances in botanical research: plant trichomes. (D.L., Hallahan \& F.C. Gray, eds.) Academic Press, San Diego, v.31, p.1-35.

WERKER, E., RAVID, U. \& PUTIEVSKY, E. 1985. Structure of glandular hairs and identification of the main components of their secreted material in some species of the Labiatae. Israel Journal of Botany 34:31-45. 